\title{
Implementation of Antitheft ATM Machine using Embedded System
}

\author{
K. Subbulakshmi, M. Meenaa Kumari, M. Jasmine
}

\begin{abstract}
Within the trendy state of affairs, money transaction is as a rule achieved with the usage of ATM. A mechanized teller machine or computerized teller laptop (ATM) is an automated media transmission system that offers a cash related groundwork's clients a secured method for performing budgetary exchanges in an open space with RFID peruser and GSM . Using an ATM, customers can reach their fiscal balances with the highest aim in intellect to gain money withdrawals and check their report equalizations. The customer then proves his identity by showing RFID tag to a peruser, then a signal is sent to sign up for that account's customer, with the main objective of "Please register pin and amount," after getting the email, then the structure approves PIN amount and after that approaches the trade, if missiles will not prepare alternatively and submit a response signal as invalid insert. After the swap is complete, the engine will pivot up to the purchaser to send compulsory add up. Concerned person will get a message through SMS by way of GSM with regard to verification and cash exchange. ATM security framework utilising GSM Module is among the interesting issues in inserted frameworks industry .For giving safety at ATMs GSM Module are controlled with the aid of utilizing Microcontroller.Typically essentially the most valuable thing to think concerning the worldwide framework for versatile correspondence is that it's a universal common. On the off hazard that you simply go in parts of world, mobile service available is GSM handiest.
\end{abstract}

Index Terms-Microcontroller, GSM Module, RFID Card Scanner, Gear motor, I2C BUS.

\section{INTRODUCTION}

This paper is ready giving a secured framework to the trade of money by means of ATM. The principle motive for this framework using RFID and GSM centered ATM cash trade model framework is for making of secured ATM exchanges with the aid of now not exposing ATM secret key to customers. Account owner ships secret key in the architecture through moblie to the GSM modem screen. The field of this framework is that we use the RFID tag as an ATM card, first we display the RFID tag to the RFID peruser, then recognize the knowledge of the document holder and distribute the message to the predefined mobile number of the cell or patron. GSM modem will send a signal to the

Revised Manuscript Received on August 22, 2019.

K. Subbulakshmi *, Department of Electronics and Communication Engineering, Bharath Institute of Higher Education and Research, Chennai, Tamilnadu, India.

M. Meenaa Kumari Department of Electronics and Communication Engineering, Bharath Institute of Higher Education and Research, Chennai, Tamilnadu, India.

M. Jasmine, Department of Electronics and Communication Engineering, Bharath Institute of Higher Education and Research, Chennai, Tamilnadu, India. owner document that will tap your secret key numbers for 4 digits. He is currently sending his secure secret key via SMS to the ATM core number. If he uses the password properly, he will receive SMS return as you kindly input your amount. We will get return SMS on the off danger that secret key is not correct as kindly input your password. Off possibility that we have logged in our document more than a modification that can be obtained, then we get SMS as you miss cash in your folder. We get money on the off risk of the trade being efficient and dc engine will transform in the layout of the building [1-6].

II. A GSM modem is a specific modem type that recognizes a SIM card and operates with a cellular operator over a subscription, much the same as a mobile phone. From the point of perspective of the flexible administrator, a GSM modem emerges easily as a mobile. This enables the computer to use the GSM modem to take over the cellular society when a GSM modem is connected to a laptop. Although these GSM modems are mostly used to provide portable internet access, huge amounts can also be used to send and accept SMS and MMS emails [7-9].

\section{BLOCK DIAGRAM DESCRIPTION}

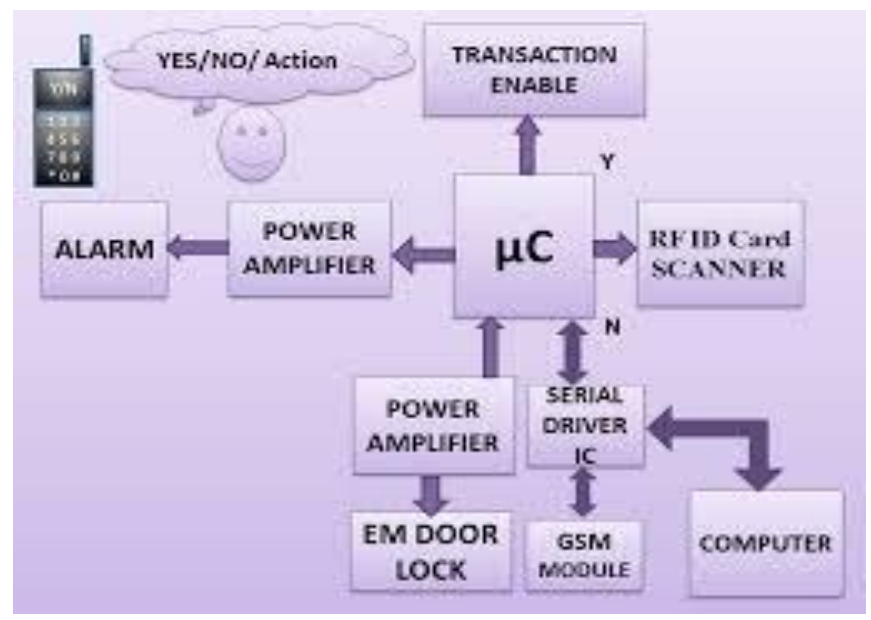

\section{PIC18F45J11 MICRO CONTROLER}

This family gives low power and elite 8-bit MCU with flexibility in peripheral with a compact package for cost delicate applications in the PIC18 J-arrangement. For low power applications some new features like deep sleep mode is included, Peripheral Pin Select for outline adaptability for mapping peripherals to I/O pins and a CTMU module for simple capacitive touch UIs.

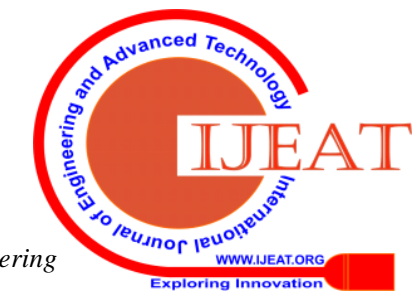


The PIC18F46J11 family is perfect for applications requiring savvy, low-power arrangements with a giant peripheral in a compact package [10-12].

\section{RFID READER}

To monitor person objects a device device used to collect know-how from an RFID tag is called radio frequency identification reader (RFID reader) Datas are transferred from tag to receiver utilising RFID reader. Nevertheless, no must scan the RFID immediately,. Additionally line-of-sight is not wanted to a reader. The variety of RFID tag shoule be within three to 300 toes, in an effort to be read.Usimg RFID technological know-how it's feasible to scan a couple of objects swiftly.Also RFID tag determine a precise product very rapidly even there are a lot of other gadgets surrounded through it. RFID labels have not supplanted standardized identifications accordingly of their cost and the must solely distinguish each thing [13].

\section{GEAR MOTOR}

The DC gear motor will control by the driver motor which will receive the commands from microcontroller when to run and when to stop .The speed of a DC motor depends on the given input current .A small piece magnet placed on the DC motor's rotor spindle, the magnet rotates at the same speed as the DC motor shaft. When the magnet starts to rotate the each reed switch produces square pulses. This is the magnetic motor speed encoder. By measuring the period between consecutive pulses the speed of the motor is calculated [14-17].

\section{GSM MODULE}

The Real Time Devices GSM35 remote GSM modem unit gives an immediate and dependable GSM association with stationary or GSM 900/1800 portable fields the world over. GSM availability is accomplished utilizing the Siemens TC35 motor. This unit works in the $900 / 1800 \mathrm{MHz}$ band supporting GSM02.22 system and administration supplier personalization. Associate any standard GSM recieving wire specifically to the OSX connector of the GSM35. The radio wire ought to be associated with the TC35 utilizing an adaptable 50-Ohm recieving wire link. In IDAN establishments the radio wire association is conveyed to the front side of the IDAN-outline. The reception apparatus utilized ought to meet the accompanying details [18].

\section{RESULTS}

Philips concocted a multi-ace serial laptop I2C .Is utilized to append low-velocity peripherals to a motherboard, hooked up framework, or PDA. The identify remains for Inter-built-in Circuit and is claimed I-squared-C in addition, erroneously, I-two-C. I2C utilizes just two bidirectional open-burn up traces. The most extreme number of hubs is naturally restricted by means of the deal with area, additionally via the mixture transport capacitance of four hundred $\mathrm{pF}$. To reinforce gear effectiveness and circuit effortlessness, Philips built up a straightforward bi-directional 2-wire transport for expert between IC manipulate. This transport is known as the Inter IC or $\mathrm{I}^{2} \mathrm{C}$ - transport. All $\mathrm{I} 2 \mathrm{C}$ - transport excellent

objects consolidate an on-chip interface which permits them to talk about straightforwardly with every other by the use of the I2C - transport. This define idea takes care of the numerous interfacing issues skilled when planning evolved control circuits. Listed below are a part of the elements of the $\mathrm{I}^{2} \mathrm{C}-$ transport $[19,20]$.

\section{CONCLUSION}

Through RFID and GSM approach, this complete execution ensures a secure and checked transaction with the lowest price and the lowest maintenance. Humanity will take advantage of fresh and guaranteed money transfers. The main thing is that the fundamental cost of the entire framework's RFID conversion is the one-time speculation needed. Account owner will use ATM card by selecting watchword by joining the bank's predefined mobile number. The appreciation included administration that this structure offers its client the legitimacy of money-related principles, the banks enhance the housing. As the globe progresses through the inescapable and a dauntless teaching task, with innovations and obviously more vulnerabilities, the portion of security-bound frameworks will certainly produce. Our implementation can therefore tackle the swap safety portion to an accurate and incredible degree.

\section{REFERENCES}

[1] Kongkham, D. \& Sundararajan, M. 2019, "Distributed wideband sensing method for faded dynamic spectrum access", International Journal of Innovative Technology and Exploring Engineering, vol. 8, no. 10, pp 4309-4312.

[2] Balaji, S., John Paul Praveen, A. \& Mohanraj, R. 2019, "Recognizable proof and analysis of palm print in biometric authentication system using bayes techniques", International Journal of Innovative Technology and Exploring Engineering, vol. 8, no. 9 Special Issue 3, pp. 1126-1129.

[3] Kavitha, G., Priya, N., Velvizhi, R. \& Allin Geo, A.V. 2019, "Paralle computation in correspondence and signal processing", International Journal of Innovative Technology and Exploring Engineering, vol. 8, no. 9 Special Issue 3, pp. 1136-1139.

[4] Hema, R., Sundararajan, M. \& Balaji, S. 2019, "Smartphone control robot with automatic firing gun", International Journal of Innovative Technology and Exploring Engineering, vol. 8, no. 9 Special Issue 3, pp. 625-627.

[5] Kaliyamurthie, K.P., Sundar Raj, B., Velvizhi, R. \& Shanmugapriya, K 2019, "Dual band paper substrate CPW antenna for wireless applications", International Journal of Innovative Technology and Exploring Engineering, vol. 8, no. 9 Special Issue 3, pp. 605-608.

[6] Geo, A.V.A., Arunachalam, A.R., Michael, G. \& Elankavi, R. 2019 "Evaluating architecture using compact modalities", International Journal of Innovative Technology and Exploring Engineering, vol. 8, no. 9 Special Issue 3, pp. 836-838.

[7] Theivasigamani, S., Jeyapriya, D. \& Anita Davamani, K. 2019 "Anamoly analyzing and exploring for wireless sensor networks", International Journal of Innovative Technology and Exploring Engineering, vol. 8, no. 9 Special Issue 3, pp. 1116-1118

[8] Jeyapriya, D., Theivasigamani, S., Velvizhi, R. \& Nandhini, P. 2019 "Program detection in wireless feeler networks", International Journal of Innovative Technology and Exploring Engineering, vol. 8, no. 9 Special Issue 3, pp. 1194-1195.

[9] Gowri Sankaran, B., Karthik, B. \& Vijayaragavan, S.P. 2019, "Image compression utilizing wavelet transform", International Journal of Innovative Technology and Exploring Engineering, vol. 8, no. 10, pp. 4305-4308.

[10] Gowri Sankaran, B., Karthik, B. \& Vijayaragavan, S.P. 2019, "Weight ward change region plummeting change for square based image huffman coding", International Journal of Innovative Technology and Exploring Engineering, vol. 8, no. 10, pp. 4313-4316. 
[11] Hema, R., Sundararajan, M. \& Balaji, S. 2019, "Smartphone control robot with automatic firing gun", International Journal of Innovative Technology and Exploring Engineering, vol. 8, no. 9 Special Issue 3, pp. 625-627.

[12] Rangaswamy, K. \& Rajabhushanam, C. 2019, "Congestion control in wireless network using TCP friendly rate control (TFRC)", International Journal of Recent Technology and Engineering, vol. 8, no. 2 Special issue 3, pp. 1598-1602.

[13] Tamil Selvan, S. \& Sundararajan, M. 2019, "Performance Parameters of 3 Value 8t Cntfet Based Sram Cell Design Using H-Spice", International Journal of Recent Technology and Engineering, vol. 8, no. 2 Special issue 5, pp. 22-27.

[14] Vinoth, V.V. \& Kanniga, E. 2019, "Steganographical techniques in hiding text images - system", International Journal of Recent Technology and Engineering, vol. 8, no. 2, pp. 6535-6537.

[15] Saravana, S., Balaji, S., Arulselvi, S. \& John Paul Praveen, A. 2019, "Reliable power quality monitoring and protection system", International Journal of Innovative Technology and Exploring Engineering, vol. 8, no. 9 Special Issue 3, pp. 644-645.

[16] Sundaramoorthy, A. \& John Wiselin, M.C. 2019, "Single patch antenna with multiple feed", International Journal of Innovative Technology and Exploring Engineering, vol. 8, no. 9, pp. 1743-1747.

[17] Velavan, R., Bharanidharan, S. \& Sheeba, B. 2019, "EMF pollution Causes, effects and protection", International Journal of Innovative Technology and Exploring Engineering, vol. 8, no. 9 Special Issue 3, pp. 1166-1168.

[18] Veer, R.A., Arulselvi, S. \& Karthik, B. 2019, "Construction of ensemble square classification approaches in MIMO OFDM", International Journal of Engineering and Advanced Technology, vol. 8, no. 5, pp. 2039-2041.

[19] Agitha, W. \& Kaliyamurthie, K.P. 2019, "Improved energy efficient in WBAN using MAC with cloud computing", International Journal of Innovative Technology and Exploring Engineering, vol. 8, no. 8, pp. 2405-2408.

[20] Kastro, G.G. \& Wiselin, M.C.J. 2019, "Design and analysis of stub loaded resonator", International Journal of Recent Technology and Engineering, vol. 8, no. 1 Special Issue4, pp. 272-283.

\section{AUTHORS PROFILE}

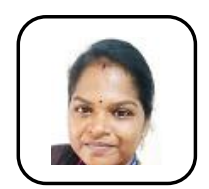

K. Subbulakshmi Assistant Professor, Department of Electronics and Communication Engineering, Bharath Institute of Higher Education and Research, Chennai, India

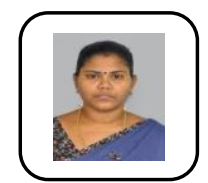

M. Meenaa Kumari Assistant Professor, Department of Electronics and Communication Engineering, Bharath Institute of Higher Education and Research, Chennai, India

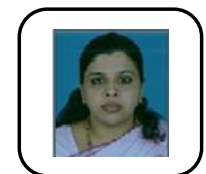

M. Jasmine Assistant Professor, Department of Electronics and Communication Engineering, Bharath Institute of Higher Education and Research, Chennai, India 